\title{
Mnemonic Mimesis against Mnemonic Coercion: Communist Romania and European Multiculturalism, in the Work of Viorel Marineasa
}

\author{
Prof. univ. dr. Caius DOBRESCU \\ Universitatea din București
}

\begin{abstract}
In his article "Mnemonic Mimesis against Mnemonic Coercion: Communist Romania and European Multiculturalism, in the Work of Viorel Marineasa" Caius Dobrescu discusses the manner in which the literary mimesis of personal memory projected at a trans-personal communitarian scale can gather, under the circumstances of a totalitarian regime, an accrued civic-political meaning. Tacitly subverting the dominant combination of ultranationalism and neo-Stalinism of the Ceauşescu regime, a whole school of Timişoara authors of fiction, literary scholars, and social historians attempted to preserve a cultural heritage empathetically shared by the ethnic cultures of the province (Romanian, Hungarian, German, Serbian). The emergence of personal, family, community histories was meant as a tacit overtake of the allegorical official history, as an expression of the re-privatization of social memory. This strategy will be exposed through an analysis of the fiction published by the Timissoara author Viorel Marineasa (b. 1944) at the end of the 1980s.
\end{abstract}

Keywords: Viorel Marineasa, mnemonic mimesis, mnemonic coercion.

Traditionally, much of the thinking and research on counteracting teleological, power-based, institutionalized collective memory was focused on the moral imperative of reconstructing the perspective of historically repressed social groups and categories. In the 1840s the French historian Jules Michelet offered the leading metaphor for this democratization of historical hermeneutics, when he described his mission as "giving a voice to the voiceless and speak to the fallen dead" (quoted in Samuel 2012: viii). Walter Benjamin's Marxian reworking of this Romantic vision was very influential for the postmodern treatment of history as social memory. His ideas on the matter are exposed in his celebrated "Theses on the Philosophy of History", which he authored in 1940 under the highly dramatic circumstances of preparing his escape from Nazi Germany (a failed attempt that, as it is widely known, prompted him into desperation and suicide). In Benjamin's view, historical memory is clearly dependent on relations of class power, which translate into the systemic violence of suppressing the sense of historical continuity and 
distinct identity of the oppressed. Nevertheless, Benjamin's redemptive perspective on history also postulated a latent apocalyptic element, a persistent streak of frustration and hope passed along from one generation to another through the collective memory of destitute underclasses (Benjamin, Theses).

The secularized apocalyptic pattern implied in Benjamin's expressed the frustrations and hopes of a highly sensitive and humane consciousness confronted with the monstrosity of the Nazi regime. Benjamin could not imagine at that point in time that a state dictatorship over memory, projected as a mere power play and as a form of suppressing alternative versions of history, could be set up in the very name of the oppressed. As a matter of fact a redemptive vision of history rooted in the radical polarization between haves and have-nots contains from the very beginning the threat of reducing the recovering of the silenced voices of history to a mechanical inversion. As long as collective memory is understood in essential and inherent connection to exercising power, the symbolic empowerment of the social memory of disenfranchisement, frustration, and resent will not lead to an empathetic celebration of common humanity, but to another kind of authoritarian narrative, to another trend of what has been called "mnemonic coercion" (Terdiman, "Given").

Nationalist ideology interprets history as a script and as a hermeneutic totality, from the perspective of a fetishized, trans-historical jus gentium. A principle understood not in its limited juridical positivity, but as a source of unlimited moral enfranchisement and empowerment of a community of the elect. Considering this line of structuring social memory and historical consciousness, Peter Burke concludes: "For Herder and his friends, the people par excellence were the peasants, because they were untainted with foreign ways and lived close to nature. The concept 'people' had nationalist and sometimes even racist overtones" (Burke "People's" 6).

The treatment of social memory by populist totalitarianism is also heavily biased, in the same vein of massively suppressing facts and data that do not suit an ideologically validated narrative pattern. Marxian dictatorships, for instance, organize social memory according to the idea that historical progress is achieved through epic class struggle. Rejecting this perspective on history and historiography, the same Peter Burke confesses: "I'm not a socialist historian; that is, I don't believe in socialist history. I believe that to use history as a weapon in political struggle is counter-productive. One comes to believe one's own propaganda, to overdramatise the past, and hence to forget the real complexity of the issues at any time. One comes to idealise one's own side, and 
to divide human beings into Us and Them" (Burke "People's" 8). A significant change of heart with respect to the politics of memory occurs the moment they are not seen as weapons in information warfare. Teleological totalitarianism and the use of historical narratives as legitimation devices for oppressive social structures can be dismantled only by transcending the logic of polarity and confrontation.

But totalitarian memory policies bring to the fore, in an "overdramatized" manner, the linear nature of institutionalized social memory in general. The intersection between memory policies and modern bureaucracies generates one-dimensional narratives patterned on identifiable causal relationships and connecting in a rigid manner spaces and temporal segments. Memory as an institution is supposed to reproduce the general structure of instrumental-organizational reasoning. There is a close link between the dominance of the linearity of bureaucratized social memory and the downplay of personal agency. Even a group of convinced Marxians, such as the Oxonian "Ruskin History Workshop Students Collective" of the 1970s collectively denounced the limits of supra-personal determinism: "As a science, history had no room for personalities, only theories of development and evolution. Detail was overlooked in the quest to explain the overall movement of social change. [...] No room here for social cameos" (RHWSC "Worker" 15). Obviously, this doesn't allude to reclaiming the determining role of "great personalities" in the making of history. The idea hereby implied was that human person is a value in itself and it has to be rescued from the devastations of self-serving structural theories.

This implied bringing to the fore not only and not primarily the personal testimony of decision-makers, but of those who were subjected to the direct and indirect, intended and unwilling effects of political decisions. This also meant, in the context of the emergence and gradual sophistication of oral history, giving such characters a voice of their own, that shouldn't simply be integrated in an overall narrative. This democracy of discourses has proven, to a significant degree, coextensive with understanding literary fiction as a privileged repository of the divergent-convergent mental universes co-existing in different societies and epochs. The global interest and assimilation of Mikhail Bakhtin theories on the structural polyphony of the novel is broadly parallel to the expansion within the world historiographical community of oral history, life narratives, the history of everyday life, etc.

The next bold step that historiography wasn't equipped to take was evolving from the interest in personal memory as an essential factor for 
reconstructing historical circumstances, to opposing personal memory to institutionalized memory, as a challenger to the position of model (or mould) for organizing the historical self-consciousness of a community. Especially in the post-WWII era it became the lot of literature to reconstruct public-collective self-representations along the sinuous lines of personal memory, within a cultural understanding of social order that gradually accommodated polycentrism, diversity, value-pluralism and a certain amount of an-archy, in the classical sense of eliminating allegedly "natural" forms of domination and privilege. Literature was on the road to a new understanding of mimesis based not only on persuasively rendering action patterns and scenarios, or on reproducing communicative situations or decisional environments, but also on emulating the constructive processes of personal memory. This statement should be kept distinct from the largely shared view that a piece of literature is structurally bound to cultural memory, i.e. tradition, by which it is preceded and permeated. Renate Lachman gives this opinion the most abstract and general expression possible by stating that: "When literature is considered in the light of memory, it appears as the mnemonic art par excellence. Literature is culture's memory, not as a simple recording device but as a body of commemorative actions that include the knowledge stored by a culture, and virtually all texts a culture has produced and by which a culture is constituted." (Lachman "Mnemonic" 301).

But the more stimulating aspect of this association is offered not by the relationship of literature with cultural/cultured memory, but with memory as such. The dialectics literature-memory resides in the capacity of the former to abstract expressive procedures and forms from the natural movements of the later. Literature deals directly with the fact that personal - that is to say lived memory is non-linear, it functions on principles of deviation, obliqueness, lateral connectivity, random association. Information is stocked in complex, corporate networks, and cannot be accessed directly. The ingress to this submerged personal heritage always depends on chance and contingency, on providential/revelatory casual intersection. But literature as mimesis of memory processes can take over such lateral and digressive processes. And it does so in order to hybridize the manifest order of institutional collective memory (the kind that can be typified and stored, that consist of categories and whose narrative concatenations can be construed as logical inferences, moral judgment or rhetorical arguments) with the rhizome, revealed through a poetic of randomness, of intimate-personal memory. 
Mnemonic mimesis replicates the free-floating and free-networking of personal memory at a larger, socially-significant scale. It focuses on the memory process, it attempts to capture (or to bracket, phenomenologically speaking) the inception and the essence of the reticulation of personal memory. In other words, it attempts an aesthetic mediation between randomness and complexity.

In the following, I will attempt to substantiate all the above theoretical considerations starting form a Romanian example of politics of memory carried out through the exclusive means of literature. I focus on the case of a Romanianlanguage literary school taking its name from Timişoara (in Hungarian: Temesvár, in German: Temeschburg, in Serbian: Temišvar), the capital city of the Banat, a former Eastern frontier province of the Hapsburg empire shared today between Romania and Serbia. The mnemonic aesthetics of the Timişoara school developed in opposition to the official national-communism of the Ceauşescu regime, a doctrine that swayed from an apparently liberal tendency of detachment from Soviet hegemony at the end of the 1960s, to a malign blend of neo-Stalinism and fascist nativism manifested especially in the 1980s (Tismaneanu). The literary subversion strategy implied the recovery of a plural historical memory empathetically shared by the ethnic cultures of the province (Romanian, Hungarian, German, Serbian - to which a whole mosaic of "minorities" should be added). In a typical display of what I called "mnemonic mimesis", the Timișoara authors rendered their sense of common heritage starting from an intensely personalized memory. "Personalized" meaning, in the present context, not only personally-experienced, but also delivered through personal contact with witnesses of events and times that could not have been directly experienced by the author/narrator. This leads to a poetics of intimate, oblique, sinuous associations which, in all honesty, exposes the flaws and vulnerability of personal memory. The art of the Timişoara school of fiction is to upgrade this self-conscious vulnerability into a cultural-political form of communitarian enfranchisement, somehow on the lines of what Václav Havel calls "the power of the powerless" (Havel). The emergence of personal, family, community histories was meant to tacitly take over the allegorical-apocalyptic, in an implicit rejection of ready-made official processing of historical experience, and as an implicit attempt of re-privatization of social memory.

The evolution of such experiments in both narrative rhetoric and identity politics came to a high degree of sophistication because of the political context in which the authors had to work. Official nationalism-nativism is only one of the factors that account for this complexly-hostile environment. Even the liberal nationalism that characterized intellectual elites opposed to the Communist 
regime, which became vocal and civically dominant after the fall of Nicolae Ceaușescu's personal dictatorship, was/is rather uncomfortable with the integral embrace of multicultural memory - and implicit critique of ethnocentric nationbuilding - of the Timişoara authors. To this we should add the ambiguities overriding - at a larger geographic and temporal scale - the attempts of pitting the nostalgia of allegedly liberal traditions of Central-Europe/Mitteleuropa against the ideological-military division of post-WWII Europe and especially against the political culture of generalized fear and mistrust imposed over the Soviet-dominated part of the continent. In the usage of 1980s East-European dissenting and countercultural intellectuals, the Mitteleuropa trope was a variation on the theme of "Finlandization": the creation of a neutral corridor of de-militarized autonomous countries between NATO and the Warsaw Pact (Le Rider 2008, Iordachi 2012: 46-9). But the Timişoara authors faced the same difficulties as notorious authors such as Milan Kundera, György Konrád, or Czesław Miłosz in disentangling a sense of constructive grass-roots centralEuropean cosmopolitanism from its historical conglomeration with Hapsburg top-down imperial(ist) ideology. The complexity and nuance required by such a critical undertaking were hard to accomplish within a doctrinaire frame, which explains why literature and literary authors won from the very beginning the upper hand on the diffusion of this (anti)political project. The polyphony, the ambiguity, the sense of nuance of literary prose offered the means for a subtle decantation of the vibrant intercultural central-European memory from its historical association with the imperial/colonial concept of Mitteleuropa, be it in its Wilhelmine, or in its Hapsburg garments (Sinnhuber "Central", Schultz "Fantasies").

The origins of the Timişoara School should be traced to the work of Sorin Titel (1935-1985), the first author who defied the old prejudice, nurtured by the powerful French influence exercised over Romanian urban mentalities since early $19^{\text {th }}$ century, of the lack of worth of "provincialism." In his novels, conceived as a family saga, Titel minutely scans the multicultural specificities of everyday life in pre- and post-WWII Banat (Clipa, Femeie, T,ara). He was also the first to process the lateral and unpredictable movements of personal memory into an elaborate mimetic aesthetics. A similar imbrication of let-go free personal memory with an acute and consistent observance of an aesthetics of mnemonic mimesis can be found in the writings of Livius Ciocârlie (b. 1935), which play with and transgress the borders between fiction, memoirs, autobiography, and cultural history (Un Burgtheater, Clopotul). The interplay between cultural and personal memory is also obvious in the baroque erudition 
of literary and cultural historian Cornel Ungureanu ("Cutia", Mitteleuropa, Geografia), as well as in the groundbreaking essays of Adriana Babeți (Europa, Banat). Ungureanu and Babeți have co-sponsored the activity of the Third Europe Foundation, a project meant to encourage translations from neighboring literatures and an interdisciplinary reflection on the joint evolutions of the cultures of East Central-Europe (Babeți \& Ungureanu Dilemele). Covering and overlapping the academic, creative, and civic fields, the work of Daniel Vighi is also an elaborate example of emancipatory memory policy based on the pluralism of historical and contemporary Banat. Besides his widely acclaimed fiction (e.g. Povestiri, Însemnări, Cometa, Trilogia) and literary and cultural history studies (e.g. Intre, Onoarea), Vighi is actively involved in the protection of the urban heritage and in development projects involving a cultural heritage dimension (Cartea). The problematization of the multicultural identity/memory of Banat was also carried out with both empirical and conceptual means through the impressive projects of social and intellectual historian Victor Neumann (e.g. Convergențe, The Temptation, Interculturalitatea), as well as of Romanian-American literary comparatist Marcel Cornis-Pope (Cornis-Pope with Neubauer and Harsanyi "Literary").

These complex literary and intellectual evolutions offer a vast material for theoretical extrapolations on what has been called "mnemonic practices" (Olick). But in the present context, for the sake of combining brevity with relevance, I chose to focus on a single author, Viorel Marineasa, and, more precisely, on the work that he published before the fall of the Communist regime. Viorel Marineasa is well-known for the refinement of his short-stories (Unelte, O cedare, Despre, Vederi), and for his pluralism and interethnic tolerance advocacy, expressed in his mordant treatment of the right-wing Romanian ideological tradition (Tradiție). He also participated in innovative oral history projects attempting to retrieve the memory of the 1950s deportation (suggested by the Soviet occupants, but carried out by Romanian authorities) to the Bărăgan deserted plains in southern Romania of ethnic Germans from the Banat, collectively and indiscriminately branded as Nazi sympathizers (Marineasa, Vighi \& Sămînță Deportarea, Vighi \& Marineasa Rusalii). But for the following analysis I selected Marineasa's first two novels (and especially the second one), because of their multileveled mnemonic techniques, as well as for their exemplary display of the manner in which the mimesis of personal memory processes and its transpersonal-communitarian rhetorical projection can gather, under the proper circumstances, an accrued political meaning. 
Litera alba (The White Letter - 1988), the first novel published by Viorel Marineasa, explores a phenomenon unique to the social life of interbellum Romania, specific to the province of Banat: peasant amateur journalists. Achim Beca, the leading character, is an independent farmer who publishes with his own resources a journal commenting local but also national political issues. The editorials, written by the owner-publisher himself, castigated the mores of Romanian party politics of the 1920s-1940s period.

Achim Beca's civic and intellectual aspirations were ahead of their time in the 1930s Romania, but contemporary readers can spontaneously identify with them. Without blowing things out of proportion, the will of the peasant editor to independent information and commentary could be construed as the remote origin of what we call today social media journalism. This is an example of how vectors of meaning released from a marginalized, repressed social memory could contribute to the closure of a historical circuit, creating an artificial sense of continuity, of civic tradition. Artificial, that is, in the original acceptation of pertaining to or provided by an art. In this case, a mnemonic art. During the illiberal 1980s, in the climate of paranoid control of information, of international isolation and economic regress in which he was writing his novel, Viorel Marineasa couldn't have anticipated the incentives communication technology was going to feed in our times to participatory democracy and independent journalism. And though, it is obvious that his minute collection of fragments of social memory is not about preserving relics, but about reframing the "present," about retrieving and reconnecting with usable pasts. Through his main character, and using literary means, Viorel Marineasa seems to enfranchise the "low," ignored and despised segments of the past in a manner similar to Western militant historians, such as, for instance, Stephen Yeo, who, in the wake of the 1980s, was stating that: "for working people to speak for themselves, about their own history, IS somehow a political act in itself. Whether such selfutterance is 'inherently socialist' is socialism's problem, and, hopefully, will never become here, as it has done in Eastern Europe, working people's problem" (Yeo "The Politics" 46).

The fact that the figure of the independent newsman, essentially different from all the role models offered by the "socialist" society, epitomizes the ethos advocated by Viorel Marineasa became apparent in his second novel, In pasaj, on which I will further focus in some detail. The novel was technically issued in 1990, after the abolition of censorship, but it had already undergone much of the exhausting process of ideological verification at the moment of the 1989 Timişoara uprising against the Communist regime. This publication detail 
indicates the relevant context in which Marineasa's strategies of insinuation and his rhetoric of diffuse personal memory should be placed.

The title of the novel is polysemantic. In pasaj, literally "in the passage," can be understood as referring to an underground passage that allows pedestrians to under-cross a crowded roundabout in the center of the city, but it could equally mean "passing through", or, more generally, "being continuously on the move." The movement (or movements), to which this later derivate meaning alludes is (are) the one(s) of personal, interpersonal, and collective memory, but also the movements between these different perspectives. In other words, the title hints to Marineasa's aesthetics of memory and to his experiments in mnemonic mimesis.

The novel intersects two temporal layers referring to different loops of the history of modern Romania. The first narrative line is the premised on the life of Augustin Hampu, a character bound to become a leading journalist of interbellum Timişoara. In the wake of WWI, the young Hampu is prosecuted for his radical stands as an activist of the party representing the Romanians of Banat, then a province of Austria-Hungary. He is convicted to death by a Hapsburg court, but in absentia, because he was cautious enough to place himself in due time outside the boundaries of the empire. His wanderings bring him to Russia, and his passionate idealism moves him to enthusiastically adhere to the Soviet Revolution. Convinced that he acts on behalf of universal freedom and democracy, he helps organizing a volunteer battalion of Romanians who, conscripted in the Austrian-Hungarian army, had become war prisoners to the Russians. But soon enough Hampu realizes the dramatic gap in the understanding of democracy that separates him from the Bolshevik authorities. The antagonism thus developed brings him a second death sentence, pronounced, fortunately for him, also in absentia. After the war and unification of Transylvania and western Banat with the Kingdom of Romania he returns home, where he founds a journal that will soon become the main political periodical of Timişoara. Even if suspicions shower over him from opposite directions - he is alternately accused of nostalgia for the Hapsburgs and of being a Soviet spy - Hampu stubbornly sticks to his agenda of condemning the corruption expanded over the Banat by the new administration centered in the Balkan new capital, Bucharest. At the end of WWII, under the circumstances of the Soviet occupation and of the forced communization of the country, Augustin Hampu is among the first of the innumerable victims of the concentration camps set up by the new power holders for their manifest, potential or imaginary opponents. Later on, in the mid-1960s, as an effect of the 
short-lived Romanian equivalent of the post-Stalinist Thaw, he will be "rehabilitated." But this occurs after his death, therefore, ironically, in absentia again.

The other temporal layer and narrative line of the novel focuses on the life and opinions of Iunian Hampu, a descendant of the interbellum democratic journalist born and raised under state socialism. Iunian is presented in a tragiccomical contrast with his spectacular ancestor. Compared to the existential parkour of Augustin Hampu, marked by a radical freedom of choice paid with a continuous state of risk which repeatedly summoned the proximity of death, Iunian manifests the characteristics of an animal raised in captivity. He enjoys a basic form of predictability, being cocooned in his social environment almost like an embryo, at the expense of all existential pathos and dignity. Compared to the events of old Hampu's biography, his are trivial, idle, otiose, and lived in a condition verging on abulia: small administrative harassments due to his "bourgeois" origins (that cannot be compared to the massive repression of the classically Stalinist 1950s), a failed marriage, the intricacies of providing basic goods typical of the penury economics of socialist states, a position of "sports instructor" made ridiculous by its lack of specific responsibilities, an unexpected short-term conscription occurring much after he had fulfilled his due military service (which, before 1989, was mandatory in Romania). Iunian Hampu has a difficult love-hate relationship with the memory of his revered forefather constantly set to him by the family as an unreachable ethical example. In spite of this, Viorel Marineasa knits between the hero and the anti-hero a web of subtle analogies placed under the sign of sexuality and death - e.g. both have complicated and difficult relationships with women, both discover at a point in their lives a disquieting nodule situated on their respective spines.

Deeply frustrated by the utter banality of his existence, Iunian takes refuge in the nostalgic evocation of pre-Communist times. A world to which he is introduced by his eccentric friend Sever Orsa, the old janitor of the people's sports club that also employs Iunian as "instructor" and proud keeper of the memory of Ulpia, the mythical soccer team of interbellum Timişoara. Contaminated with Orsa's fascination over this golden lineup, Iunian embarks on a personal inquiry on the destinies of its members. He traces and interviews the survivors, immersing himself in the vibrant multicultural atmosphere of those times. The Ulpia team was a microcosm illustrating the ethnic mosaic of historical Banat, the players were Hungarian, German, Jewish, Romanian, Serbs. Their personalities and destinies turn out to have been very different. Some of them became opportunists of the new regime, some went through a total 
psychic and physical breakdown when leaving sportive life, only a few managed to resist in a dignified manner to the corrosion of aging and of the Communist politics of fear and forced compliance. Nevertheless, the youthful energy, the physical beauty, the fair-play idealism of the historical Ulpia transforms the memory of this team of "people of old" into a symbol of civic trust and dignity opposed, in the witnessing consciousness of Iunian, to the ethical entropy and instrumentalized nationalist fanaticism of the "present", and tacitly resonating with the heroic memory of Augustin Hampu.

The complex mnemonic mimetics of Viorel Marineasa need to be described at several levels. First of all, the cogito of Augustin Hampu is rendered by a narrative voice from the off, but with digressions, glides, and returns that indicate the processes of personal memory. A highly relevant fact is that Marineasa fictionalized the life of the democratic political activist and journalist Sever Bocu (1874-1951), whose memoirs he actually edited later, at his own publishing house, Editura Marineasa (Bocu). The parallel reading of the two texts makes obvious that the memory discourse of the novel is the expression of mnemonic mimesis, leaning not only on the representation of the meanderings of intimate recollection, but also on intense sensory evocations, sometimes emphasized from existing notations in Bocu's memoirs, but more often than not figments of Marineasa's imagination. While conserving mannerisms of polite conversation or high oratory of the 1900s, the mnemonic rhetoric devised by Marineasa attempts to transmogrify the rather dry and formulaic discourse of Sever Bocu into Augustin Hampu's embodied memory. This accounts for a narrative equivalent for what has been described in visual arts theory as "the art of sense memory" which "aims to constitute a language of subjective process (specifically of affective and emotional process) to complement history and to work in a dialectical relationship with common memory" (Benett "The Aesthetics" 29).

In its Proustian rhetorical imbroglio the discourse of the old Hampu has nevertheless a presumed finality, the remembrance of things past can be construed as an intentional quest for meaning. But the manner in which memory is experienced in the discourse of the young Hampu is profoundly different. The flashes from his own history seem random and unconnected to a process of introspection. As a matter of fact the absence or quasi-nullity of his own significant memories is the incentive for his amateur inquiry into the biographies of epic local soccer players. In so doing, the witnessing consciousness of this second temporal loop of the novel displaces the accent in "personal memory" from the workings of memory, to the recovery of the 
personal. Iunian's exploration is the figuration of a manner through which the memory of the person/personal, slightly distinct from personal memory as such, can be saved from the combined destructive effects of natural oblivion and propaganda-manufactured social memory. The extraction of best and worst case scenarios form the life stories of the immortal twelve of legendary Ulpia is a policy of memory aimed at seizing the inflections of dignity from broken existential trajectories, as well as retrieving the moments of vulnerability form the exemplary CVs.

But there is another powerful indication of the consistency of the subjacent vision on mnemonic mimesis in Marineasa's novel. Even if affinities and allusions link the two temporal layers of the novel, the actual contact between them is not concluded within the plausibility conventions of the fictional world. Their encounter is hypothetical, is a virtual space-time continuum that bears all the features of a sensitive, responsive, unpredictable personal memory without actually being one. Marineasa reproduces the chemistry between past and present, that usually takes place in a cognitive entity, in a consciousness, and expands it to an inter- and transpersonal level. Which becomes also socially relevant, to wit "inter-national", taking into account that, according to the aphoristic title of a famous contribution to the study of cultural memory, "the past is a foreign country" (Lowenthal The Past).

The laterality of memory is similar to the deviations of the hypothetically parallel trajectories of atomic particles in the Lucretian universe, which create swerves, clinamena, disturbing jams and vortexes within an eternal downward flux. The deviations of private memory also cause such lateral, transversal swerving of conventional historical information. This apparent chaos seems a hostile environment to predictability and intelligibility, therefore incompatible not only with the cognitive, but also with the moral reasoning. Yet, in a manner analogous to Lucretian cosmology where the swerves come to constitute the order of objects of the real world, under the guidance of artistic intelligence the memory swerves end up creating new, bottom-up, rhizomatic collective identities.

More than that: as the narrative we discussed above consistently indicate, memory is an expression of both moral freedom and moral order. Memory is a virtual space where, on the one hand, actual chains of actions come to closure as meaningful sequences, but where, on the other hand, they can be contrasted and morally weighed in retrospect against different but possible and plausible alternative sequences of events, courses of action, and patterns of meaning. By suspending temporality - not in the sense of unidirectional flow, 
but rather in that of pressure to act, more often than not in highly undetermined and unpredictable decisional environments - memory instates the conditions for inner deliberation.

Viorel Marineasa created socially-relevant, communitarian, essentially democratic deliberative environment by bringing together the memory of "high" historical events, to which Augustin Hampu seems to be a direct, even if tragically misfit, participant, and the everyday, "popular" heroism embodied in the moral ingenuity of peasant amateur journalism or the Ulpia soccer team at its apogee. Marineasa seems to "morph" these elements into a sense of the "monumental" (Rigney "From Colelctive"), i.e. of a robust, even if nonessentialist, celebration of traditional civic virtues. But his characters are hardly impenitent conservatives incapable of understanding the "sense" of history - as they could have been automatically labeled by the propaganda machine of the Communist governors of post-bellum Banat. The fact that they preserve, against all odds, the inner vertical shape of the Old Regime is not nostalgia for a wellestablished hierarchy of statuses - but a heroic form of redeeming individual self-confidence and self-respect under a political regime that tended to completely evacuate such values. The living memory of an order rooted in rational assent, in free acceptance of customary social boundaries meant ultimately to protect privacy and self-esteem, seemed to threaten the very foundation of an order based on repression and fear. The "conservative", who is supposed to manifest a high respect for social order and place, ironically becomes a rebel and an anarchist, under the circumstances of universal social control of the East-European post-WWII era.

\section{Works Cited}

Babeți, Adriana, and Cornel Ungureanu (eds). Europa Centrală: Memorie, paradis, apocalipsă (Central Europe: Memory, Paradise, Apocalypse). Iaşi: Polirom, 1998.

Babeți, Adriana. Dilemele Europei centrale (The Dilemmas of Central Europe). Timişoara: Mirton, 1998.

Babeți, Adriana (ed.). Banat: Un Eldorado aux confins. Paris: Centre Interdisciplinaire de Recherches Centre-Européennes, 2007. 
Benjamin, Walter. "Theses on the Philosophy of History", in Benjamin, Illuminations, ed. H. Arendt, tr. H. Zohn, New York: Schocken Books: 253-64, 1968.

Bennett, Jill. "The Aesthetics of Sense-Memory: Theorising Trauma Through the Visual Arts." In Susannah Radstone and Katharine Hodgkin (eds.). Regimes of Memory. London-New York: Routledge: 27-39, 2003.

Bocu, Sever. Drumuri și răscruci. Memorii (Roads and Crossroads. Memoirs). Ed. Viorel Marineasa and Cornel Ungureanu. Timișoara: Editura Marineasa, 2005.

Burke, Peter. "People's History or Total History." In Samuel: 4-9, 2016.

Ciocârlie, Livius. Un Burgtheater provincial (A Provincial Burgtheater). Bucharest: Cartea Românească, 1984.

Ciocârlie, Livius. Clopotul scufundat (The Sunken Bell). Bucharest: Cartea Românească, 1988.

Cornis-Pope, Marcel with John Neubauer and Nicolae Harsanyi. "Literary Production in a Marginocentric Cultural Node: The Case of Timişoara." In Marcel Cornis-Pope, John Neubauer (eds.). History of the Literary Cultures of East-Central Europe: Junctures and Disjunctures in the 19th and 20 ${ }^{\text {th }}$ Centuries. Amsterdam-Philadelphia: John Benjamins, 105-124, 2006.

Erll, Astrid and Ansgar Nünning (eds.). Cultural Memory Studies: An International and Interdisciplinary Handbook. Berlin: Walter de Gruyter, 2008.

Havel, Václav. "The Power of the Powerless." In Living in Truth, ed. Jan Vladislav, tr. Paul Wilson. Boston: Faber and Faber, 36-122, 1986.

Iordachi, Constantin. “The Quest for Central Europe: Symbolic Geographies and Historical Regions." In Zlatko Šabič, Petr Drulák (eds.). Regional and International Relations of Central Europe. London-New York: Palgrave Macmillan, 40-61, 2012.

Lachmann, Renate. "Mnemonic and Intertextual Aspects of Literature." Erll \& Nünning: 301-10, 2008.

Le Rider, Jacques. . "Mitteleuropa as a lieu de mémoire." Erll \& Nünning: 37-46, 2008.

Lowenthal, David. The Past is a Foreign Country - Revisited. Cambridge UK-New York: Cambridge UP, 2015.

Marineasa, Viorel, Daniel Vighi, Valentin Sămînță. Deportarea în Bărăgan. Destine, documente, reportaje (Deportation in Bărăgan. Destinies, Documents, Reportages). Timișoara: Mirton, 1996.

Marineasa, Viorel. Litera albă (The White Letter). Timișoara: Facla, 1988.

Marineasa, Viorel. În pasaj (Passing Through). București: Editura Militară, 1990. 
Marineasa, Viorel. Unelte, arme, instrumente (Tools, Weapons, Instruments). Bucharest: Cartea Românească, 1992.

Marineasa, Viorel. O cedare in anii '20 (A Capitulation in the 1920s). BucharestPitești: Paralela 45, 1998.

Marineasa, Viorel. Tradiție supralicitată, modernitate diortosită. Publicistica lui Nichifor Crainic și a lui Nae Ionescu, la o nouă citire (Overvalued Tradition, Straightened Modernity. A New Reading of the Journalistic Works of Nichifor Crainic and Nae Ionescu). Timișoara: Editura Universității de Vest, 2004.

Marineasa, Viorel. Despre Banat, în registru normal (On the Banat, On a Normal Tone). Reșița: Modus PH, 2009.

Marineasa, Viorel. Vederi din Timişoara (Postcards from Timişoara). Iași: Institutul European, 2010.

Neumann, Victor. Convergențe spirituale: Studii privind dimensiunea interculturală in Europa centrală şi de est (Spiritual Convergences: Studies Concerning the Intercultural Dimension in Central and Eastern Europe). Bucharest: Eminescu, 1986.

Neumann, Victor. The Temptation of Homo Europaeus. Tr. Dana Miu. Boulder: East European Monographs; Columbia UP, 1993.

Neumann, Victor. Interculturalitatea Banatului (The Interculturality of the Banat). Iași: Polirom, 2012.

Olick, Jeffrey K. "From Collective Memory to the Sociology of Mnemonic Practices and Products." In Erll \& Nünning: 151-162, 2008.

Rigney, Ann. "The Dynamics of Remembrance: Texts Between Monumentality and Morphing." In Erll \& Nünning: 345-356, 2008.

Ruskin History Workshop Students Collective. "Worker-historians in the 1920s." In Samuel: 15-20, 2016.

Samuel, Raphael. Theatres of Memory: Past and Present in Contemporary Culture, London-New York: Verso, 2012.

Samuel, Raphael (ed.). People's History and Socialist Theory. (History workshop series). Oxford-New York: Routledge, 2016.

Schultz, Hans-Dietrich. "Fantasies of Mitte: Mittellage and Mitteleuropa in German geographical discussion in the 19th and 20th centuries." Political Geography Quarterly V.I . 8, No . 1, October, 315-339, 1989.

Sinnhuber, Karl A. "Central Europe, Mitteleuropa, Europe Centrale: An Analysis of a Geographical Term." Transactions and Papers (Institute of British Geographers), No. 20: 15-39, 1954. 
Terdiman, Richard. "Given Memory: On Mnemonic Coercion, Reproduction and Invention". In Radstone and Hodgkin: 186-201, 2003.

Tismaneanu, Vladimir. Stalinism for All Seasons: A Political History of Romanian Communism. Berkeley: U of California P, 2003.

Titel, Sorin. Clipa cea repede (The Fleeting Moment). Bucharest: Eminescu, 1979.

Titel, Sorin. Femeie, iată fiul tău (Woman, Behold Your Son). Bucharest: Cartea Românească, 1983.

Titel, Sorin. Țara îndepărtată. Pasărea şi umbra (The Remote Country. The Bird and the Shadow). Bucharest: Eminescu, 1989.

Ungureanu, Cornel. “Cutia Pandorei: Pentru o istorie alternativă a literaturilor din Europa Centrală" (Pandora's Box: For an Alternative History of the Literatures of Central Europe). A treia Europă 1: 55-64, 1997.

Ungureanu, Cornel. Mitteleuropa periferiilor (Mitteleuropa on the Peripheries). Iaşi: Polirom, 2002.

Ungureanu, Cornel. Geografia literaturii române, azi. Vol. IV: Banatul (The Geography of Romanian Literature, Today. Vol. IV: The Banat). Bucharest-Piteşti: Paralela 45, 2005.

Vighi, Daniel (ed.). Cartea străzii Eugeniu de Savoya (The Book of Eugene of Savoy Street). Timișoara: Brumar, 2009.

Vighi, Daniel, Viorel Marineasa. Rusalii '51. Fragmente din deportarea în Bărăgan (Pentecost '51. Fragments of the Deportation in the plains of Bărăgan [of ethnic Germans from the Banat]). Timișoara: Editura Marineasa, 2004.

Vighi, Daniel. Povestiri cu strada depozitului (Stories with the Warehouse Street). Bucharest: Cartea Românească, 1985.

Vighi, Daniel. Insemnări despre anii din urmă (Notes on the Latter Years). Bucharest: Cartea Românească, 1989.

Vighi, Daniel. Intre hanger și sofa. Literatura în epoca veche românească (Between the Dagger and the Ottoman. Literature in Romanian Pre-Modernity). Timişoara: Editura Marineasa, 1998.

Vighi, Daniel. Cometa Hale-Bopp (The Hale-Bop Comet). Iaşi: Polirom, 2007.

Vighi, Daniel. Onoarea și onorariul (Honor and Honorarium). Bucharest: Cartea Românească, 2007.

Vighi, Daniel. Trilogia Corso (The Corso Trilogy). București: Cartea Românească, 2015.

Yeo, Stephen. "The Politics of Community Publications." Samuel: 42-8, 2016. 